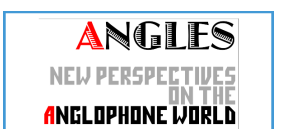

ANELOPHONE WORLI

\section{Angles}

New Perspectives on the Anglophone World

$4 \mid 2017$

Unstable States, Mutable Conditions

\title{
Two Versions of the Truth: Class and Perspective in Early Captivity Narratives
}

\section{Tobias Auböck}

\section{(2) OpenEdition}

12 Journals

\section{Electronic version}

URL: https://journals.openedition.org/angles/1440

DOI: $10.4000 /$ angles. 1440

ISSN: 2274-2042

\section{Publisher}

Société des Anglicistes de l'Enseignement Supérieur

\section{Electronic reference}

Tobias Auböck, "Two Versions of the Truth: Class and Perspective in Early Captivity Narratives", Angles [Online], 4 | 2017, Online since 01 April 2017, connection on 08 June 2022. URL: http:// journals.openedition.org/angles/1440 ; DOI: https://doi.org/10.4000/angles.1440

This text was automatically generated on 8 June 2022.

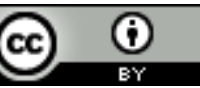

Angles est mise à disposition selon les termes de la Licence Creative Commons Attribution 4.0 International. 


\title{
Two Versions of the Truth: Class and Perspective in Early Captivity Narratives
}

\author{
Tobias Auböck
}

1 For a major part of his tenure, Thomas Jefferson, third president of the United States, found himself in the middle of a controversy about whether or not North-African corsairs who had been attacking American merchants should be bought off or fought against. Because of the young country's tumultuous history, the American population had grown increasingly weary of conflict and many (including the second president, John Adams) were set on doing everything in their power to avoid military involvement in foreign countries. Initially, it had been possible not to get directly involved in the diplomacy of this conflict which involved a number of Christian and Muslim countries around the Mediterranean. Religious orders (such as the Trinitarians) had ransomed American captives from the city-states of Algiers, Tripoli, Tunis and Salé in Morocco, places that were the corsairs' safe havens and the main causes for Jefferson's sleepless nights. The dissolution of the order of the Trinitarians in the course of the French Revolution in effect ended this strategy and put the responsibility back into the hands of politicians (Sears, 39). Eventually, however, the American politicians who argued for military intervention gained the upper hand, as more and more tribute was being paid and, slowly but surely, the payments came to exceed the calculated cost of an armed conflict. Consequently, the US navy was reactivated from its post-revolutionary war retirement, an initiative which resulted in two Barbary Wars in the first half of the $19^{\text {th }}$ century. Even though these wars eventually proved to be victorious for the US, they did not come without American losses, as is exemplified by the history of the sailing frigate USS Philadelphia. ${ }^{1}$

2 As Thomas Jefferson had rejected Tripolitan demands for tribute, the city's Bashaw Yusuf Karamanli had the American embassy's flagstaff chopped down in the spring of 1801, a decision which essentially amounted to a declaration of war. The USS Philadelphia came into use in the third year of the resulting conflict. On October 31, 1803 
it ran aground in the treacherously shallow waters of Tripoli's harbor. This incident is at the center of two conflicting first-person accounts - the captivity narratives of William Ray and of Jonathan Cowdery. ${ }^{2}$ Through this paper, my intention is to show how the social standing and rank of the two witnesses influenced both their perception of their experiences and, consequently, their representation of captivity in North Africa. I aim to do this by first presenting and comparing the two accounts, thereby briefly touching upon questions of authenticity. I shall subsequently situate these two accounts within their contemporary literary context. But first, it is necessary to provide some additional historical contextualisation.

\section{Historical Context}

3 It seems that, once the ship had run aground, the crew of the USS Philadelphia was unable to get the ship afloat again and, following a short siege, captain Bainbridge surrendered to the aggressors without having suffered a single American casualty. All on board were taken prisoner and transported into the town of Tripoli, where some of them were forced to work at reinforcing walls and other defense mechanisms, while the high-ranking officers were held in relative comfort. A few Tripolitan guards were left behind to guard the ship. As the loss of the ship to the Tripolitans would have signified a tremendous disgrace for the US navy, Commodore Preble agreed to a proposed plan to destroy the ship. So, on 16 February 1804, lieutenant Stephen Decatur, Jr. and a few of his men approached the USS Philadelphia with a small ketch, overpowered the guards and blew up the ship (Field 52).

Until peace was eventually reached in 1805 , the American prisoners were held captive in Tripoli. The few detailed sources that we have paint conflicting pictures as to how they fared. Jonathan Cowdery, the ship's surgeon and therefore a member of the officers' rank, portrays his captivity in his published journal American Captives in Tripoli; or, Dr. Cowdery's Journal in Miniature (1806) as having been generally pleasant (given the circumstances). On the other hand, William Ray, a common sailor, describes gruesome scenes in his account, Horrors of Slavery (1808). Ray never tires of pointing out the bias and other flaws in Cowdery's account, which had appeared two years before his own. Ray seems to be especially angered by the fact that Cowdery writes as if the lenient treatment he personally received had also been extended to the rest of the crew: "You will, therefore, please to remember, that when the Doctor says we, it is the very same as if he had said we officers only; for he does not think proper to descend to the task of relating how the crew were provided for, or whether they were but half alive or all dead" (Ray 2008: 57). He comments on and criticizes Cowdery's Journal, arguing that the officer had been treated a lot better than the majority of the rest of the crew whose plight is hardly mentioned at all in his account. Ray thus opens his eighth chapter in the following fashion:

I shall now take some notice of extracts from Doctor Cowdery's journal, as published in the Balance, of Hudson, and republished in the Albany Register. As far as he adheres to strict veracity, I shall coincide with his observations; but when he deviates from correctness, or exaggerates on facts, take the liberty of differing with the learned Doctor's diary. (Ray 1999: 188).

5 The fact that there are two captivity narratives available to us dealing with the same event is fairly unusual. And it is even less common to have a text that makes direct reference to another narrative. Furthermore, insofar as the narratives of Cowdery and 
Ray do diverge to a considerable extent, they offer a striking instance of the inherent difficulties involved in the genre, raising fundamental questions about authenticity and the interpretation of such narratives.

\section{Two Competing Narratives}

6 For a number of reasons, today's readers of the narratives might be tempted to place their trust in that of Ray, rather than in Cowdery's account. Not only was it published after Cowdery's Journal and comments on it, it also offers a perspective that is hardly present at all in Cowdery's narrative: the plight of the common mariner. However, it is important to bear in mind that Ray readily admits to following a personal agenda in publishing his Horrors of Slavery. If Ray makes use of the shortcomings of Cowdery's account, this is only a starting point. His professed goal is to reveal injustices within the US navy:

Be assured, it shall be my business and delight, to expose, in the following pages, every act of cruelty, every abuse of authority, that I witnessed, during my continuance in the service of the United States. (Ray 2008: 30)

7 So even as he laments the harsh treatment which he and his comrades had received at the hands of the Tripolitans, he ultimately lays the blame for the situation endured by his comrades and by himself not on their captors, but to a large extent on their officers. He does this by creating a clear demarcation between forces of good and evil. Through the use of a distinctly anti-authoritarian disposition, Ray opposes the officers and the ordinary crew. He largely absolves the Muslim population from responsibility in the latter's plight. Or, rather, he portrays the enmity between captors and captives as an effect of the prevailing circumstances, which are grounded in religious differences. For Ray, American captivity in Tripoli is comparable to a natural catastrophe - something which could have been avoided by his superiors (the officers) and which was completely mishandled once it actually occurred.

It is not, however, unusual for writers of his time to address these kinds of social issues, and as Cathy Davidson points out, even such seemingly un-American topics as "class" are occasionally discussed:

'There is no class in America' has been a recurring theme from the nation's inception. Yet no one reading the body of fiction produced in the early Republic would find a representation of a classless society. On the contrary, early American novelists present (and often critique) the American version of a non-egalitarian class system. (10)

9 However, in order for his criticism to work, Ray has to portray his captivity as having been exceedingly cruel, thereby discrediting Cowdery's report, which, according to Paul Baepler, "reads more like the journal of an inconvenienced gentleman on holiday" (Baepler 18). Cowdery and the other officers never went hungry, their movements were hardly restricted, and they were even given the opportunity to do some sightseeing:

Jan. 3. - Went to the Bashaw's garden, where I met the minister and the prince[,] the Bashaw's eldest son. They politely conducted me through the garden, which was ornamented with a great variety of fruit trees, loaded with fruit, particularly with oranges, lemons and limes. John Hilliard died in the evening. (Cowdery 166) mention the plight of the remaining crew, is a dimension that infuriated Ray. Consequently, what Cowdery makes out to be a somewhat unpleasant, but still bearable 
situation, is in Ray's account turned into an unmitigated torment, fraught with often life-threatening consequences.

So while Cowdery only mentions in passing that killings did actually occur during their time in captivity, as can be seen from the quote above, Ray describes in detail the deaths of his comrades. He also devotes large sections of his narrative to the practice of religious conversion, a common topic in many captivity narratives (less so, however, in Cowdery's Journal). He recounts the case of quartermaster John Wilson, who allegedly began to work for the Tripolitans shortly after the capitulation of the USS Philadelphia. He routinely provided them with classified information, including the whereabouts of a chest filled with gold, which Wilson claimed the Americans had dumped into the Tripolitan bay. Apparently, Wilson did not return to the States along with the rest of the crew upon their release: "The captain told him that he would have him hanged for a traitor if ever he returned to America, and in a violent passion threw his chain at him. A few days afterwards, Wilson, probably fearing the reality of his threats, put on the turban, and confirmed his apostasy" (Ray 2008: 67).

Cowdery mentions this incident only briefly, in a tone suggesting a degree of indifference: "Wilson had turned traitor, and given the enemy all assistance in his power. He now acts as overseer over our men" (Cowdery 164). It is possible that Cowdery may have tried to make light of Wilson's conversion, as it not only shed an unfavorable light on the officers' treatment of their subordinates (one possible explanation for his actions), but it also depicts American soldiers as opportunistic (Rojas 174). As a member of the officer corps, Cowdery would have been aware of these implications and would also have considered the implications of publication from a political perspective. Ray's arguments, on the other hand, can claim corroboration from Wilson's actions, which explains why Bainbridge's threats (which rendered Wilson's desertion unavoidable) feature so prominently in this depiction.

How much blame Ray actually laid at the captain's feet also becomes apparent when we compare the conflicting descriptions of the circumstances that had led to what (in Ray's eyes) was the ship's premature surrender. This is what Cowdery has to say on the matter:

Nov. 3. - The Bashaw sent for the carpenter to go on board the ship; he went and found six feet water in the hold. The carpenter's crew and fifty men were ordered and carried on board to work at night. A gale of wind and heavy sea hove the ship off the rocks and the carpenter returned. (Cowdery 163)

The degree to which rank influenced not only the captivity itself, but also the reports of the captives, is remarkable. Unlike Ray, Cowdery implies that a great effort was needed in order to get the USS Philadelphia back afloat. This statement is in agreement with the official narrative, according to which captain Bainbridge did everything in his power to save the ship and to protect the United States navy from a humiliating defeat. Ray, however, portrays this event differently:

In fact, the Turks were so pusillanimous, that after our colours were struck, they dare not, for they did not attempt to come any nearer, until we sent a boat, and persuaded them that it was no farce, no illusion, assuring them that our frigate had in reality struck to one gun-boat, and entreated them to come and take possession of their lawful booty! (Ray 2008: 54)

The difference in the social statuses of Ray and Cowdery also manifests itself in their conflicting portrayal of the Tripolitans' attack on the ship. Cowdery falls back on the stereotypical dichotomies between the supposedly uncivilized Eastern culture as 
opposed to the civilized West, as exemplified by his highlighting the infighting among the attackers once it came to the question of dividing up the booty:

After the flag of the Philadelphia was struck, (says the Doctor,) and the officers and crew waiting the pleasure of their new masters, the Tripolitan chiefs collected their favourites, and, with drawn sabres, fell to cutting and slashing their own men who were stripping the Americans and plundering the ship. They cut off the hands of some, and it is believed, several were killed. (Cowdery 161)

Ray, while he also mentions these attacks within the ranks of the Tripolitans, tends to depict them in a manner that is a lot less gruesome:

It is true there was a sort of mutiny and clashing of arms amongst them; but for my part I never saw any hands amputated, nor do I believe there were any lives lost; for myself and a hundred others were in the ship much longer than the Doctor, and none of us ever saw or heard of this carnage amongst themselves. (Ray 1999: 188)

Traditionally, in Europe (and by extension, the American colonies), infighting within an army had been considered to constitute a category of extremely barbaric acts, clear evidence of a lack of civilizing progress. Unsurprisingly, Cowdery - a member of the American officer corps - makes a point of perpetuating this trope. Even though his depiction of the remainder of his captivity turns out to be a lot less cruel than that of Ray, this episode demonstrates in particular that he identifies a fundamental difference between the European and the Arab world.

According to Ann Thomson, such a perspective is precisely the reason why texts such as Cowdery's often feature a milder assessment of an individual captivity. She argues that from the $18^{\text {th }}$ century onwards the European powers no longer considered the North-African states (and Algiers in particular) as powerful enemies that operated at eye level with them. Consequently, most observers regarded the possibility of an invasion and colonisation of North Africa as being only a matter of time:

This gradual and uneven transformation of ways of looking at the region and its inhabitants accompanies ever more insistent calls for an expedition against the corsairs, ending finally in demands for a conquest and then colonisation of Algeria. [...] There is thus an evident connection between the depreciation of North Africans, both racially and in terms of their degree of civilisation, on the one hand, and the growing desire to exercise control over the region, on the other. (Thomson 144)

19 It is noteworthy, however, that certain stereotypes can be found independently in Ray's as well as in Cowdery's depiction. Both highlight the longevity of the native population and also discuss their use of magic. Cowdery, for instance, writes:

Sept. 9. - The Bashaw took me with him, and his suit to his country seat where we spent the most of the day. About 5 o'clock P.M. we went to see the great Marabewt, or Mahometan priest, in whom the Bashaw had great faith, and thought he could foretel [sic] events. It was said by the Turks, that he foretold the stranding and capture of the Philadelphia; and that he got offended with the Bashaw and caused and foretold her being burnt. (Cowdery 176)

While Ray also mentions this prediction, there is a curious difference in his version, insofar as the priest is a clairvoyante, i.e. a woman:

In the morning, about eight o'clock, an old sorceress came to see us. She had the complexion of a squaw, bent with age, ugly by nature, and rendered frightful by art. [...] This frightful hag is held, by the Bashaw and all the Tripolitans, in the highest veneration, not only as an enchantress, but as a prophetess also. It is said by them that she predicted the capture of the Philadelphia, and believed by them that the ship struck the shoals in consequence of her incantations." (Ray 1999: 190) 
21 Ray demonstrates another tendency typical of the American relation of North-African captivity: in order to cope with the unknown, authors often relied on terminology that suggested familiarity. In Ray's case, there is a recourse to the term "squaw," derived from the eastern Algonkin languages, meaning woman, which shows his familiarity with Indian captivity narratives, such as Mary Rowlandson's famous narrative published in 1682 (Peskin 164). However, taken together, these tendencies are much more prominent in Cowdery's writing, where there is a clear and explicit attempt to highlight the exotic nature of the hero's adventure.

22 Peskin explains by arguing that ordinary crewmembers, insofar as they are mostly members of the poorer social classes, attached a much higher importance to the concept of freedom - especially after the revolutionary war in the US. He finds an explanation for this tendency in the fact that sailors already had to give up parts of their freedom when entering the navy and submitting themselves to the rules of their captain's "kingdom" (Peskin 168). This was clearly true for William Ray. He appears to have loathed the restrictions imposed on the freedom of an ordinary sailor. His anger was further increased once it became apparent that, despite all these restrictions, the navy was still unable to guarantee the safety of those under its command.

The various disparities in the narratives shed light on the difficult question of the historical reliability to be credited to these texts. Cowdery was apparently keenly interested in portraying himself in a heroic light, highlighting the civilisational differences between Europeans and the native population, while explaining away certain medical actions on his part while in captivity (such as his work as a personal surgeon for Tripoli's bashaw, in the course of which he had even saved the latter's son - one of the reasons for his relatively light treatment as a captive).

Arguably, Cowdery was well aware of the fact that his readers might not regard these actions lightly or favorably, and that they might even have career-damaging implications for him. Consequently, he made a point of recounting events that highlight his patriotism and even heroism:

Aug. 5. - The American squadron anchored off Tripoli, I was ordered to dress the wound of a mameluke, who had his hand shattered by the bursting of a blunderbuss. I amputated all his fingers but one, with a dull knife, and dressed them in a bungling manner, in hopes of losing my credit as a surgeon in this part of the country, for I expected to have my hands full of wounded Turks in consequence of the exploits of my brave countrym[e]n. (Cowdery 171)

The history of captivity narratives bears witness to numerous episodes of this sort, where the captive is the member of an honoured, sought-after profession. Thomas Pellow, for instance, recounts a similar story from his time as a surgeon in Moroccan captivity. He writes that he recommended the application of ground pepper to cure certain eye conditions (Colley 95). Statements of this kind were meant to show that even in captivity and in a capacity as the involuntary servant of the enemy, one did one's best to inflict damage on the hostile society. In addition to that, Cowdery explains that he was not even aware of the fact that there was a chance for his redemption:

The Bashaw sent for me, and, agreeably to his orders, I took a seat by his side. [...] He asked me what I thought my country would give for me. I told him I did not know. He said he would not take twenty thousand dollars for me; to which I replied, 
that I might then expect to remain in slavery for life. He patted me on the shoulder and said, I must then content myself to stay with him. (Cowdery 172)

\section{different. Not only did he try to correct Cowdery's misrepresentations, he also} commented in a highly sarcastic manner on some of his alleged heroic deeds:

After they had borrowed about ten dollars of the Doctor, and wrested his surtout from under his arm, [Cowdery] says- "Whilst they were picking its pockets, and quarreling with each other for the booty, I sprung for the next boat which was waiting for me. In my way I met a little fellow who seized me and attempted to get off my coat, but I hurled him to the bottom of the boat," \&c. This was certainly the most heroic action that has ever been read of any of the Philadelphia's officers. (Ray 1999: 188)

Ray makes it clear that he had a strong anti-authoritarian agenda. He does not even try to hide the fact that his primary purpose was not the objective retelling of events. $\mathrm{He}$ starts his narrative with the following poem:

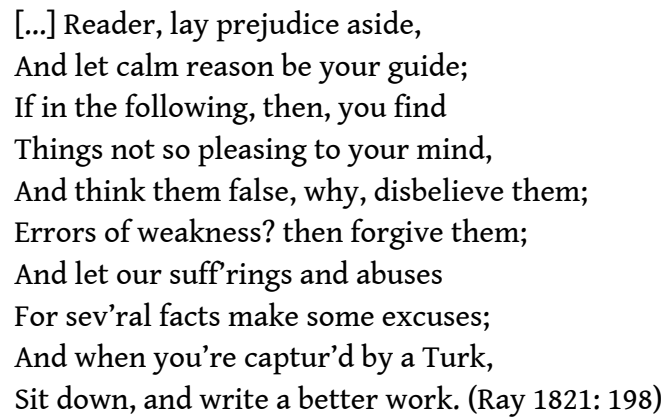

This short passage reveals a number of striking features. As stated above, Ray wrote and published his narrative as a response to Cowdery's Journal. The latter's experiences had been well known to the public even before the publication of his text, as parts of his account had appeared in various newspapers and public demand had ultimately prompted Cowdery to publish a complete version of his Journal (Baepler 160). It follows from this that the relatively lenient treatment which Cowdery and the rest of the officers had received was also known to the public. Among other things, this is what Ray is hinting at, as he anticipates and seeks to ward off a possible hostile response to his narrative, when he writes: "If in the following, then, you find / Things not so pleasing to your mind[.]"

And yet he admits freely that there could also be inaccuracies in his own narrative, in all likelihood caused by the tremendous experiences he had to go through: "And let our suff'rings and abuses / For sev'ral facts make some excuses[.]" Here Ray addresses the issue of his own credibility - a crucial factor in any captivity narrative, particularly for today's generation of historians. Granted, while there certainly were narratives that featured assertions of truth and anticipations of disbelief (Robert Adams's heavily annotated publication about his alleged trip to Timbuctu comes to mind), Ray's poem is one of the very few cases that actually discusses the possibility of its own fallibility.

The reasons for Ray's outspoken attacks on Bainbridge and Cowdery become clear when we take into consideration that he was also pursuing certain ideological goals. Contrary to what the title of his narrative (Horrors of Slavery) suggests, he was not interested in criticizing the concept of slavery per se. His main objective was to denounce the inhumane treatments experienced by common mariners at the hands of their superiors. 
31 The pursuit of social goals by way of one's writing was not something unusual for the contemporary literary scene. Quite the contrary. These didactical aspects contributed significantly to a text's overall interest and to the enjoyment it offered:

$[\mathrm{H}]$ owever alien to moderns such tone and aims may be, the didacticism of the early novel is central to the conception of the species. Its origins are so tied up with needs of contemporary readers and its early history is so dependent on the didactic assumptions in popular non-narrative forms that to miss or excuse its characteristic didacticism is to misappreciate its features and misdefine its nature. (Hunter 226)

32 As J. Paul Hunter explains here in Before Novel (1992), genres such as that of captivity narratives bridge the gap between fiction and non-fiction and can be termed "popular non-narrative forms." Even though historianstoday sometimes overlook this, it is important to factor in the circumstances of a text's creation. After all, the poem which introduces the narrative is also an indication that Ray had certain literary ambitions. This is further confirmed by Ray's later publications.

\section{Captivity Narratives: A Popular Genre}

After Horrors of Slavery, Ray embarked on a literary career and gained a considerable, albeit geographically limited, reputation. As pointed out by Hester Blum, an obituary that appeared in the Daily National Journal bears witness to this fact:

He has lately published a neat pocket volume of his poems, which should be owned by every American patron of genius, particularly, as we presume, in becoming possessed of it, he will contribute to the relief of his widow and daughters, who are left to struggle alone in embarrassed circumstances. (Blum XXVIII, Fn 21)

This epitaph shows that the monetary aspect is not to be overlooked when discussing these narratives. Despite his moderate literary success, Ray and his family seem to have suffered considerable financial hardship. It is not a far stretch to argue that this situation could have influenced his thought process concerning a potential publication. In her study The Unvarnished Truth: Personal Narratives in Nineteenth-Century America (2000), Ann Fabian highlights the factor that monetary considerations often took on for the authors of captivity narratives:

For some, telling a tale of captivity provided a means to demonstrate that life among the 'aliens' had not altered them beyond recognition. Stories helped former captives rejoin the society of neighbors and friends. Others had more concrete goals in mind; they hoped to gain compensation for property lost or the means to ransom friends and family still held captive. (5)

Ray's hopes were not unreasonable. It was well known that these narratives could attract a considerable audience. James Riley's captivity narrative, Loss of the American Brig Commerce (1817) - the most successful of all so-called American Barbary Coast captivity narratives - eventually went through at least 38 different editions (Baepler 307). This is what Ray also seems to have had in mind. He sent his account to a number of high-ranking officials, including Thomas Jefferson and James Madison, respectively third and fourth presidents of the United States. Both seem to have reacted kindly to Ray's narrative, which prompted him to follow up by sending them another letter that included an appeal for donations (Blum XXIII). After his request went unanswered, he wrote a third letter, stating that he assumed that his second letter had not reached its addressee: 
I am not willing to suspect that the Chief Magistrate of a free people, who owes his political existence to the suffrage of men of all ranks, would treat with silent contempt the honest effusions or well-meant offering of one who has greatly suffered in the cause of that Government over which he presides. (Blum XXVIII)

Ray seems to have been under the impression that the presidents, in their capacity as commanders-in-chief, held some responsibility for the failures of the officers, which included Cowdery's misrepresentation of events. After all, one of Ray's main arguments is that Cowdery aimed both to portray his own actions in captivity as being outstandingly heroic and to whitewash some of his more questionable deeds.

\section{Novels and Authenticity}

Ray's and Cowdery's texts were written in a period characterized by an increasing demand for captivity narratives from North Africa. The genre's popularity led to the publication of a surprising number of fictional pseudo-authentic captivity narratives, such as the ones allegedly written by Eliza Bradley or Maria Martin, both of which went through dozens of editions (Baepler 305-9). Whereas these fictional texts certainly had a great influence on contemporary ideas and images of Islam, North Africa and the Arab world in general (especially in those cases where the texts were initially received as authentic), they are hardly ever used today as historical sources. On the other hand, those texts which are based on actual events, are still drawn upon in numerous historical and popular historical studies dealing with this area at this period. Often, the fact that parts of these narratives can indeed be historically verified is taken as justification for regarding the whole narrative as authentic.

Some of those who argue in favor of the accuracy of the narratives in question tend to disregard the literary features and tropes that are to be found in many autobiographical texts, including the accounts of captivity and slavery. The authors of captivity narratives from the turn of the $18^{\text {th }}$ to the $19^{\text {th }}$ century, especially those from America, often accorded themselves a considerable literary freedom when recounting their stories - in some cases clearly doing so in order to profit from the then-occurring rise of the sentimental novel, which went hand in hand with increasing readership numbers. Cathy Davidson devotes her study on Revolution and the Word: The Rise of the Novel in America (2004) to this issue, pointing out the importance of the increasing supply of books (e.g. through British imports) and highlighting the fact that authors began to cater to readers from the middle class rather than to the gentry (75). Coupled with this, there was a stylistic shift towards a more general appeal - not to everybody's liking:

[T] he continuing censure of the early novel rivaled the novel's growing popularity, and that incongruity took a variety of unusual forms. Thus, before approximately 1790, many books sold in America that we would now unquestionably define as novels (e.g. Tristram Shandy) were advertised otherwise ('a sentimental history'). (103)

This shows that when Ray and Cowdery published their narratives, the novel was still trying to find its place in the American literary scene. Ray's narrative in particular (though not actually sold as a novel) features some of the genre's characteristic elements, which shows how unclear such texts are in their generic identity:

But, by the turn of the century, a whole range of nonfictional reading materials, including sketches, captivity narratives, and travel pieces, were advertised as 
novels. Yet the censure of the form, emanating from the pulpit and the press, remained potent enough so that, until well into the nineteenth century, virtually every American novel somewhere in its preface or its plot defended itself against the charge that it was a novel, either by defining itself differently ('Founded In Truth') or by redefining the genre tautologically as all those things it was presumed not to be-moral, truthful, educational, and so forth. (103)

40 happened in Ray's life, the narrative also followed a very specific mode of composition, which satisfied a certain "taste for wonders," as described by Hunter (210). In his narrative, Ray introduces stylistic elements usually associated with the novel. This can be observed in many captivity narratives and shows that, however factual or educational some of these narratives claimed to be, a considerable part of their raison d'être was their entertainment value. (1797) - does in fact deal with North African captivity. Many of the main characteristics of Puritanism had long inhibited the development of any proper fictional genres in the US, with the consequence that entertainment literature was regarded as inconsequential and a waste of time. Hence, initially, the fact that the American literary scene was dominated by poetry for even longer than in European countries, as it enabled authors to convey important life lessons in a fashion that was both short and aesthetically pleasing (Slotkin 224).

Most literary publications, until the late $18^{\text {th }}$ century, had appeared either in the form of poetry or had dealt with actual events, often in combination with religious eulogies. A Narrative of the Captivity and Restoration of Mrs. Mary Rowlandson is a prime example of that category. Her text published in 1682 deals with her captivity among Native Americans during the so-called King Phillip's War. Faithful to the literary traditions of the time, her narrative is littered with quotes from the Bible. Also, in structural terms, it evokes a series of religious resonances, as she portrays her time in captivity as a godly trial. In doing so, her narrative closely mirrors the style of contemporary American providence books. Both genres have in common the fact that they demonstrate a strong tendency to mold unrelated events into a coherent narrative. These text forms thus anticipate major elements from the modern novel as they introduce an overarching storyline as a basic literary compositional tool. The resulting basic plotline makes it possible to superimpose a deeper moral (often of a religious nature) upon the series of events brought together in the narrative. ${ }^{3}$

This structure is highly prevalent in the narrative consolidation of the basic American and strictly Puritan belief in providence, according to which humans cannot control or alter their fate, but where they can deduce from their success in life a presumption as to whether or not they are predestined to belong to the chosen ones. As often noted by sociologists, including Max Weber, this idea has many reflections in American literary history, the most prominent probably to be found in Benjamin Franklin's autobiography (Weber 13).

However these ideas were also quite prevalent in early captivity narratives (such as the one written by Mary Rowlandson) and can still be felt at the beginning of the $19^{\text {th }}$ century - not only in the texts written by Ray and Cowdery, but also in completely fictional captivity narratives, such as Eliza Bradley's 1818 account of her alleged captivity in Morocco. These narratives demonstrate the continuing influence of Puritan ideals and indicate that such texts were under the obligation to at least appear to serve 
a certain purpose (such as highlighting God's mercy), instead of functioning first and foremost as mere entertainment literature.

\section{Conclusion}

Hunter argues that many of these proto-novelistic publications today tend to be misinterpreted. Some of those texts, which to present-day readers seem to fulfill purposes that are solely educational or instructional, were read by contemporary $19^{\text {th }}$ century readers for their own personal pleasure:

$[\mathrm{H}]$ istorical evidence suggests that many real eighteenth-century readers seem actually to have enjoyed the tones and intentions of the texts their culture characteristically produced, even though to take such a pleasure in being told what to do [...], bears no relationship to any idea of pleasure that we in our time honor. (Hunter 227)

The didactical aspects, which were so prevalent in many of these narratives, only added to their appeal. In an environment dominated by the puritanistic disregard for, and suspicion of, pleasurable diversion in all forms (including prose literature and theater), the constant reiteration of the claim of the authenticity of the texts in question sought to reassure the readers as to their educational value. The considerable number of completely fictional narratives which feature the same assertions bears witness to that tendency. As has been argued by Paul Baepler, Eliza Bradley's fictional work, entitled An Authentic Narrative of the Shipwreck and Sufferings of Mrs. Eliza Bradley (1820), a perfect example of this category, shows that a certain number of these assertions soon became more of a literary trope than a genuine piece of information (Baepler 21).

Especially during the $19^{\text {th }}$ century, truth was more of a "social convention," as Fabian puts it. In her discussion of slave narratives, she remarks: "To hold [former slaves] to the facts and nothing but the facts sometimes stripped from narrators the right to interpret their stories and artfully embellish their experiences" (Fabian 98). The same holds true, of course, for authors of captivity narratives, including those under discussion here.

This is all the more true given that Jonathan Cowdery and William Ray published their texts at a time when the literary world was going through a series of fundamental changes. The US was about to gain its literary independence and was attempting to rid itself of its European-influenced past. Judging from the style of his narrative, Cowdery does not seem to have had any great literary aspirations (his account is basically written in the form of a factual diary). Ray, however, was clearly more concerned with the literary aspects of his narrative. Whereas the former declared his Journal to be an authentic replication of the diary he had kept in captivity (a claim discernable from its title American Captives in Tripoli; Or Dr. Cowdery's Journal in Miniature Kept During His Late Captivity in Tripoli), Ray does not hide the fact that he considers his publication to constitute a work of art. His later publications, and also the structure of his narrative and the poems he included, indicate as much. Stylistically, Ray followed the literary Zeitgeist which was predominantly influenced by the rise of the sentimental novel: "In general, the sentimental novel opposes intuition to rationality; disjuncture, episode, and effusion to continuity and plot; artlessness and sincerity to art and literary calculation; and emotional to verbal communication" (Braudy 12). Ray's narrative conforms to many of these traits. As he readily admits in his opening poem, some of his 
recollections might be distorted, due to the emotional stress he went through. Instead of having a strictly focused plot, his narrative is divided into heterogeneous fragments of memory. Absolute sincerity seems to be his main objective, while a particular emphasis is placed on the underlying emotional agenda (ie. the denunciation of the malpractices of American officers).

So what then can these texts tell us about American captivity in North Africa? We could provide an answer to this question by raising another one: what do these texts tell us about the factors which might have influenced their writing? Approaching the question of authenticity from this perspective can help us significantly in relation to the task of assessing their historical value. If we consider the above-mentioned factors when analyzing the narratives, not only do we gain deeper insights into the origins of this genre, we can also perhaps gain greater insight into the actual lives of American captives in North Africa during this period.

\section{BIBLIOGRAPHY}

Adams, Robert. The Narrative of Robert Adams, a Barbary Captive. Ed. Charles H. Adams Cambridge: Cambridge UP, 2005.

Baepler, Paul. White Slaves, African Masters: An Anthology of American Barbary Captivity Narratives. Chicago: U. of Chicago P., 1999.

Blum, Hester. “Introduction”. In Ray 2008. X-XXVIII.

Bradley, Eliza. An Authentic Narrative of the Shipwreck and Sufferings of Mrs. Eliza Bradley [...]. Boston: James Walden, 1820. In Baepler 1999. 247-284.

Braudy, Leo. “The Form of the Sentimental Novel.” NOVEL: A Forum on Fiction 7.1 (1973): 5-13.

Colley, Linda. Captives: Britain, Empire and the World, 1600-1850. London: Pimlico, 2003.

Cowdery, Jonathan. American Captives in Tripoli, Or, Dr. Cowdery's Journal in Miniature: Kept During His Late Captivity in Tripoli. Boston: Belcher and Armstrong, 1806. In Baepler 1999. 159-185.

Davidson, Cathy N. Revolution and the Word: The Rise of the Novel in America. New York: Oxford UP, 2004.

Fabian, Ann. The Unvarnished Truth: Personal Narratives in Nineteenth-Century America. Berkeley: U. of California P., 2000.

Field, James A. America and the Mediterranean World, 1776-1882. Princeton, N.J: Princeton UP, 1969.

Hunter, J. Paul. Before Novels. New York: W.W. Norton, 1990.

Peskin, Lawrence. Captives and Countrymen: Barbary Slavery and the American Public, 1785-1816. Baltimore: John Hopkins UP, 2009.

Ray, William. Horrors of Slavery: or, The American Tars in Tripoli. 1808. Ed. Hester Blum. London: Rutgers, 2008. 
Ray, William. Horrors of Slavery, or the American Tars in Tripoli. Troy, NY: Oliver Lyon, 1808. In Baepler 1999. 188-203.

Ray, William. Poems, on Various Subjects..., Religious, Moral, Sentimental and Humorous. Auburn: Doubleday, 1821.

Rojas, Martha. “'Insults Unpunished': Barbary Captives, American Slaves, and the Negotiation of Liberty.” Early American Studies: An Interdisciplinary Journal 1.2 (2003): 159-186.

Sears, Christine. American Slaves and African Masters: Algiers and the Western Sahara, 1776-1820. New York: Palgrave Macmillan, 2012.

Slotkin, Richard. Regeneration Through Violence: The Mythology of the American Frontier, 1600-1860. Middletown, CT.: Wesleyan UP, 1973.

Shaw, Elijah. A short sketch of the life of Elijah Shaw: who served for twenty-one years in the Navy of the United States, taking an active part in four different wars between the United States \& foreign powers; namely, First-with France, in 1798; Second-with Tripoli, from 1802 to 1805; Third-with England, from 1812 to 1815; Fourth-with Algiers, from 1815 to 1816; and Assisted in subduing the pirates, from 1822 to 1826, and in 1843 entered on board the Old Ship Zion, under a new commander, being in the 73[r]d year of his age. Rochester, N.Y.: Strong \& Dawson, 1843.

Thomson, Ann. Barbary and Enlightenment: European Attitudes towards the Maghreb in the $18^{\text {th }}$ Century. New York: Brill, 1987.

Tyler, Royall. The Algerine Captive, Or, the Life and Adventures of Doctor Updike Underhill, Six Years a Prisoner Among the Algerines. Ed. Caleb Crain. New York: Modern Library, 2002.

Weber, Max. Die protestantische Ethik und der „Geist“ des Kapitalismus. Eds. Klaus Lichtblau/Johannes Weiß. Bodenheim: Athenäum Hain Hanstein, 1993.

White, Hayden. Tropics of Discourse: Essays in Cultural Criticism. Baltimore: John Hopkins UP, 1978.

\section{NOTES}

1. This paper was funded by the FWF Austrian Science Fund Project "ESCAPE (European Slaves: Christians in African Pirate Encounters): Barbary Coast Captivity Narratives (1550-1780)" / American Studies Department at the University of Innsbruck.

2. There is a third account, written by Elijah Shaw and published in 1843. However, it features very little personal information about his time in Tripolitan captivity, which is why it is not discussed in this study.

3. In the early 1970s, Hayden White drew attention to this practice of combining factual writing with plot structures usually associated with fiction, and introduced the term "emplotment" to discuss fictional elements in historiography that he believed were largely being ignored (White 82). 


\section{ABSTRACTS}

This study deals with early American narratives about North African captivity. The focus is put on two widely differing narratives that were written about the same event (the capture of the USS Philadelphia in 1803), one by an officer, the other by a regular sailor. The aim of this study is to show how class, monetary considerations and literary ambitions influenced the seemingly factual retellings of those events.

L'étude analyse les premiers récits américains de captivité barbaresque. Deux récits présentant de notables divergences et portant sur le même épisode (la capture de la frégate USS Philadelphia en 1803) sont examinés, l'un des récits étant celui d'un officier, l'autre celui d'un simple marin. L'objet est de montrer comment les questions de classe sociale, les enjeux monétaires et les ambitions littéraires ont influencé le compte-rendu, en apparence factuelle, des événements.

\section{INDEX}

Mots-clés: récits de captivité, Tripoli, Côte des Barbaresques, Jefferson Thomas, guerre révolutionnaire américaine, littérature américaine

Keywords: captivity narratives, Tripoli, Barbary Coast, Jefferson Thomas, American Revolutionary War, American literature

\section{AUTHOR}

\section{TOBIAS AUBÖCK}

Tobias Auböck is a PhD student at the University of Innsbruck, where he also received his Diploma in History, as well as English and American Studies, specializing in American Barbary Coast captivity narratives. He received the Austrian Fulbright Prize for best thesis in American Studies. From October 2013 to March 2014, he worked as an assistant at the American Corner Innsbruck, an information platform that is anchored at the Department of American Studies at the University of Innsbruck and the U.S Embassy in Vienna. From July 2014 until July 2016, he was research assistant for the FWF-funded project "European Slaves: Christians in African Pirate Encounters (ESCAPE: Barbary Coast Captivity Narratives 1550-1780)." He is a recipient of the Richard \& Emmy Bahr grant for his dissertation project. In 2016, he was awarded the Austrian Ministry of Science Fellowship and is now working on his dissertation at the Center for European Studies (Center Austria) at the University of New Orleans. Contact: tobias.auboeck [at] gmail.com 